\title{
"A URCA É O PARAÍSO DOS CEGOS": MOBILIDADE URBANA, ACESSO À CIDADE E TERRITORIALIZAÇÃO
}

\author{
Olivia von der Weid ${ }^{1}$
}

\section{Introdução}

Bavcar (2000), em relato sobre o itinerário da sua vida com a cumplicidade da cegueira, diz que não pode correr como antes e teria quase se esquecido disso se certo dia crianças não tivessem perguntado a ele por que caminha tão lentamente. Considera que sua vida é menos agitada, mais imóvel do que a das outras pessoas. Vai menos até as coisas, se move menos e em círculos estreitos. $\mathrm{O}$ espaço se restringiu e deve tocá-lo para conhecê-lo ou então identifica-lo pelos seus ruídos.

Em um dos manuais de educação que analiso para essa pesquisa, especificamente voltado para a formação de professores nas técnicas de Orientação e Mobilidade (OM) para pessoas cegas, indica-se que a mobilidade seria a maior perda na cegueira (Brasil, 2003). Ela é definida como a habilidade de uma pessoa em se deslocar intencionalmente da posição em que se encontra para outra desejada, reagindo a estímulos internos e externos. Vygotsky (1997) coloca que, com a cegueira, o que se perde é principalmente a orientação espacial e a liberdade de movimentos.

O treinamento de $\mathrm{OM}$ consiste em um programa educacional de múltiplos estágios onde habilidades motoras e de orientação são treinadas para ensinar a pessoa com deficiência visual como se orientar em ambientes pequenos ou largos, como ser eficientemente guiada por outra pessoa e como proteger o seu próprio corpo. Parte do treinamento é especialmente dedicada ao uso da bengala longa, que é fundamental para a marcha e a exploração sistemática de lugares desconhecidos. O objetivo último, nem sempre atingido por todos, é alcançar a "mobilidade independente e segura", por meio da incorporação de uma série de técnicas, mas também por uma educação da atenção aos sentidos e aos sinais significativos do mundo. Uma espécie de (re)classificação ou (re)organização do mundo a partir de materialidades ou referenciais não visuais.

\footnotetext{
${ }^{1}$ Universidade Federal do Rio de Janeiro, Brasil.
} 
Nesse artigo procuro abordar a relação de pessoas cegas com o cenário urbano do Rio de Janeiro a partir de seus deslocamentos, pelos sentidos de familiaridade ou distância atribuídos aos bairros, aos caminhos ou trajetos percorridos. Representações da cidade e de locais específicos desta cidade. Parto de uma abordagem fenomenológica do espaço para entender como pessoas cegas desenvolvem seus percursos urbanos e as suas percepções destes lugares.

Para tanto, são analisados manuais de formação de professores na área da deficiência visual produzidos pelo Ministério da Educação (MEC) e material de campo realizado no Instituto Benjamin Constant (IBC). No material de campo encontram-se entrevistas com profissionais do Instituto, observação participante de atendimentos em Orientação e Mobilidade $(\mathrm{OM})$ da área de reabilitação, material do curso de formação em técnico de Orientação e Mobilidade, de 40 horas, realizado em abril de 2012 no IBC, além de entrevistas com pessoas cegas.

Para abordar a relação com o espaço para além do olhar, o sentido da distância, foi preciso primeiro uma atenção ao corpo como locus de um ser no mundo, e as possibilidades de apreensão desse mundo, do espaço ao redor, a partir de uma não visualidade. Neste artigo foco especialmente nas pistas do solo e na conformação de mapas ou rotas, que entram em cena para participar da configuração do lugar.

Apesar de também utilizar o termo "espaço" para falar das relações com o entorno, é preciso esclarecer que a abordagem que se desenvolve aqui, por trazer especialmente características experienciais de pessoas cegas com o ambiente, seus aspectos vividos ou subjetivos, está mais próxima da noção mais fenomenológica de lugar. Entendido como uma arena de ação que é ao mesmo tempo física e histórica, social e cultual a noção de lugar contrasta com a noção de espaço - vazio volumétrico nos quais as coisas são posicionadas - abstração que desencorajaria explorações mais experienciais (Tuan, 2001; Casey, 2001)

Em um segundo momento procuro abordar a mobilidade e o acesso à cidade a partir dos caminhos percorridos, os locais evitados ou os conhecidos, o uso que se faz do transporte público, o imperativo da ajuda em seu deslocamento. Trata-se do direito à cidade que, para Lefebvre (1969), não pode ser concebido como simples direito de visita, mas sim como direito à vida urbana, significando o acesso a espaços, equipamentos, instituições, serviços que transcendem os limites da vida cotidiana na vizinhança de um bairro. 
Pensando o espaço urbano como marcado por códigos e regulações sociais particulares e pela presença irrefutável do outro, busca-se entender a circulação e a ocupação destes lugares por pessoas cegas e as possibilidades de territorialização de bairros e percursos. Abordo o sentido de familiaridade ou distância dos trajetos, maior ou menor autonomia no deslocamento. Trato ainda das relações que se estabelecem no espaço público a partir do imperativo da ajuda. Procuro entender a importância e o lugar dessa dimensão no acesso de pessoas cegas aos territórios urbanos.

\section{Percorrer o ambiente para percebê-lo - rotas, linhas e mapas}

Casey (1996) propõe uma reversão fenomenológica para compreender o sentido de lugar e o conhecimento local enquanto uma percepção corporificada, expressão concreta e localizada, ao invés de uma ideia de espaço englobante, abstrato e generalizado. $\mathrm{O}$ autor acredita que há, desde o início, um ingrediente na percepção que é um meio que comunica o que significa estar nos lugares. Estamos nos lugares porque estamos nos nossos corpos.

Pelas sensações corpóreas de corpos cegos no mundo podemos aceder a novas medidas espaciais. A situação de corpos marcados pela não visualidade enfatiza os papéis que sensações corpóreas provocadas por sons, cheiros, direção, toque, temperatura e deslocamento do ar, desempenham para a composição espacial do mundo. Nessa composição corpoespacial não há um sentido necessariamente privilegiado, os indícios se multiplicam para formar uma unidade que, apesar de englobante, é aberta. Em constante atualização, vai ganhando novas informações a cada instante, a cada distância percorrida, absorvidas por todo esse aparato perceptivo. Renata nos fala sobre esse funcionamento.

Você anda de bengala então você percebe através do pé, através da pele, as coisas que estão acontecendo. Por exemplo, você percebe o chão... a audição ajuda porque você percebe se o espaço é aberto, se o espaço é fechado, como é que é, se tem som, se não tem, da onde o som está vindo... e o olfato para você perceber o cheiro da onde você está. Não sei se tem um sentido principal. Tem as marcações táteis também, uma escada, um degrau, uma diferença de piso, sei lá, de repente uma pilastra, uma porta. Porque a verdade é que quando a gente anda, aqui na escola mesmo, eu estou andando do outro corredor para esse daqui, eu sei que quando entra aqui nesse corredor, lá do saguão, o ambiente fica mais fechado, o som muda, o piso muda, eu sei que tem um risco no piso, perto das pilastras, eu sei que tem pilastras no corredor. Para você o risco não é importante porque você enxerga. Normalmente para a gente esse risco é importante, perto da pilastra. 
Como fica explícito no depoimento de Renata um referencial importante são as marcas do caminho. Um quebra-molas, um risco no chão, uma pilastra, um bueiro na rua, todas essas coisas podem virar indícios de um lugar, marcações que orientam. O meio fio, o muro das casas, de uma instituição ou estabelecimento como linhas guias. Camila descreve a linha de chegada em sua casa:

\begin{abstract}
Eu pego a bengala na frente, sigo uma rua e vou embora. Eu sempre pego uma linha guia. Para eu chegar em casa é a guia do posto. Eu salto no ponto, vou na mesma calçada, vou, vou, vou. Aí quando eu sinto que eu caí na rua assim, eu passo para o outro lado, atravesso a rua que não tem movimento e acho a rua do posto de gasolina, que é do outro lado. Eu ainda passo um pouquinho da rua, aí achei a guia, eu vou voltando pela parede e vou embora.

O: uma linha guia é uma coisa que você sempre busca?

Sempre, em qualquer lugar, qualquer lugar eu busco.
\end{abstract}

Em um manual de formação de professores para educação de deficientes visuais (Brasil, 2001), afirma-se que o treinamento de OM consiste basicamente em ajudar pessoas cegas a, primeiro, saberem onde estão espacialmente e para onde querem ir (orientação) e, depois, traçar um plano para chegar lá (mobilidade). Coloca-se que o professor, quando vai ensinar orientação à criança cega, deve se ater a três questões: Onde estou? Para onde quero ir (onde está o meu objetivo)? Como vou chegar ao local desejado?

Camila diz que depois que ficou cega ela mudou alguns hábitos. Um deles foi justamente esse de fazer um planejamento, uma rota do deslocamento, antes de sair para qualquer lugar.

Eu sempre faço uma programação antes, eu procuro saber o quê que eu tenho que fazer, como eu vou fazer, não posso sair com a cara e a coragem achando que também vai... - 'Camila, vai lá na minha casa?', - 'onde você mora?', -'em tal lugar', eu falo assim -'olha, eu estou saindo de Madureira, como é que eu faço?’. Eu não tinha esses cuidados, de se programar, agora eu me programo direitinho.

No ponto de partida do deslocamento, a pessoa cega traça uma rota, planeja previamente a sua navegação - onde estou? Para onde quero ir? Como vou chegar lá? A sua orientação está voltada para um destino e nesse sentido poderia se afirmar que seguem uma linha de transporte, de conexão ponto a ponto, conforme descrita por Ingold (2007). Mas o deslocamento, por outro lado, se realiza ao longo do caminho, contando com as marcas, as pistas, os traços do ambiente no percurso que se faz através dele. Dada a largada, para alcançar o seu destino o deslocar de pessoas cegas 
se aproxima ao do caminhante (wayfaring) de Ingold (2007). Sua orientação e seu passo estão continuamente relacionados ao monitoramento perceptivo de um ambiente que se revela ao longo do caminho. Ele observa, escuta e sente enquanto segue, todo o seu ser está alerta para as incontáveis pistas que, a cada momento, podem demandar pequenos ajustes. Locomoção e percepção estão intimamente vinculados em sua caminhada. Renata conta que, mesmo estando dentro de um táxi, percebe o deslocamento e o lugar onde se encontra por meio da propriocepção e do movimento.

Quando eu estou chegando aqui eu passo pelo viaduto e passo pela praia de Botafogo. No viaduto eu sei que o carro sobe e desce, aquela é a minha referência para me mostrar que está chegando perto do Instituto. Aí depois tem uma curva e tal, a curva é outra referência. Isso a gente percebe. Porque, não sei, vai que alguma vez eu esteja dentro do táxi e o motorista resolva me levar para outro lugar? Tem que ficar atenta.

Para o ambiente se tornar conhecido é preciso traçar as suas linhas, incorporar os seus contornos ao longo das repetidas passagens que se faz ali. Caetano fala sobre o novo lugar onde mora e como faz para chegar e sair de sua casa e Jair conta sobre o seu caminhar por locais conhecidos:

O local é novo, eu não conhecia. Estou me adaptando. Mas aí eu já tracei, já fiz o traçado de lá. Quer dizer, é uma rua que passam duas estradas, uma numa extremidade, outra na outra. Eu fico entre uma estrada e outra. Já sei que moro mais perto da primeira, que é onde eu pego o ônibus quando eu venho de manhã. Quando eu vou, eu vou pelo outro lado, pela outra estrada, porque aí eu não tenho que atravessar a rua. Eu chego em casa, vou e volto, sem ter que atravessar nenhuma das duas estradas, porque eu vou por uma e volto pela outra.

Os lugares que eu sempre passo são os lugares que eu conheço, né? Quando eu saio de casa eu já sei que ali tem um vaso assim, depois um pé de não sei o quê. Aí eu passo ali, bato a bengala, aí eu desço, pego a rua, antes de pegar a rua eu... audição para ver se vem carro, não vem carro, eu atravesso. Aí tem outra rua, eu vou andando, não vem carro eu atravesso. E vou para o ponto de ônibus.

Não só a memória é redundante, para Calvino (2002), a própria cidade redunda, se repete para fixar alguma imagem na mente.

Podemos pensar que a locomoção de pessoas cegas se encontra em algum lugar entre o transporte e a caminhada. O deslocamento está ligado a locais específicos, se orienta a um destino, mas o caminhante que sai de um local e chega em outro, no meio tempo, está inteiro no movimento e no ambiente que percorre para chegar até lá. 
Ele se desloca ao longo, seguindo linhas guias, traçados, buscando pontos de referência, internalizando as curvas, as marcas e o movimento do corpo no caminho. $\mathrm{O}$ andar de cegos se aproxima ao monitoramento que os Batek realizam ao caminharem em uma trilha (Ingold, 2007). Mas pessoas cegas, ao invés de buscarem plantas úteis para colher ou traços de outros animais em sua caminhada, buscam pistas espaciais - sonoras, táteis, olfativas, de temperatura, de movimento, do tempo e da distância percorrida - que possam ser indicativas do caminho, do ambiente, dos objetos, estabelecimentos, construções, ruas, outras pessoas, buracos, carros, das superfícies no mundo.

\begin{abstract}
Primeira coisa, me chama a atenção o chão, o solo onde eu piso. Eu procuro sempre identificar alguma coisa no chão. Qualquer coisa diferente ali que dê para eu identificar. Acontece muito de eu ir num lugar que eu não conheço a primeira vez acompanhada de alguém e conseguir voltar a segunda sozinha. Exatamente por isso, pelas marcas no chão. Antes de entrar, eu já procuro vir assim procurando alguma coisa ali na calçada, prestando atenção no solo e no trajeto que eu estou fazendo pra chegar até a porta de entrada, esse é o primeiro passo. Essa coisa de se eu vou fazer um movimento para a esquerda, para a direita, se eu vou seguir em frente, eu procuro marcar sempre isso. Ali na caixa cultural, por exemplo, eu entrei na Almirante Barroso aí eu procurei marcar o tempo que eu levaria para chegar mais ou menos próximo ali da entrada. Aí outro dia quando eu voltei sozinha, pelo tempo que eu andei da esquina, eu parei e disse assim, acho que eu já estou em frente. Aí eu perguntei pra um casal que vinha passando "por favor, vê se eu estou em frente ao número 25?". Aí o casal "ah tá, só passou um pouquinho. Como a senhora sabia?", eu digo "é porque eu tenho mais ou menos a noção do tempo". (Angela)
\end{abstract}

No manual de educação analisado (Brasil, 2001), indica-se que a proposta pedagógica com uma criança cega deve contemplar a vivência e o conhecimento do espaço interno e externo, tocar, explorar paredes, corredores, portas, janelas, móveis, brinquedos, para poder formar o mapa mental do ambiente, que permitirá um deslocamento seguro. Renata nos fala sobre o processo de formar o mapa mental de um lugar.

Quem direciona (a bengala) é a própria pessoa, que faz o mapa mental e estabelece as referências dos espaços. E isso cada um tem as suas, dependendo do espaço, dependendo do que a pessoa acha mais importante. Cada um tem uma forma de fazer referência.

A geografia tem pensado o conceito de mapa mental como representações do vivido, em que uma imagem do lugar se apresenta em uma forma que carrega histórias concretas e simbólicas, revelando como o lugar é compreendido e 
vivenciado (Nogueira, 2002; Kosel, 2013). Essas representações espaciais-mentais são construídas tendo como base a percepção própria dos lugares experimentados e, portanto, partem da realidade. Os mapas mentais são saberes que expressam uma relação de vida com o lugar. No conceito geográfico humanista de mapa mental está embutida duas ideias que nos interessam para compreender o processo de construção de mapas mentais por pessoas cegas - a compreensão da percepção como saber primeiro e do mundo como um lugar de existência.

No depoimento de Angela é possível identificar algumas das suas referências para formar um mapa mental, ou uma imagem, de um lugar que conhece pela primeira vez. Ela diz que ao percorrer por meio do tato os móveis, os materiais, a parede, consegue formar uma imagem - a sua imagem - do ambiente.

Se for um lugar que eu esteja à vontade, eu procuro passar a mão na parede, na porta, para eu poder através dali ir criando a imagem daquele ambiente, entendeu? os designs da porta, da parede.... Um lugar assim que eu possa identificar móveis, mesa, balcão, aquela coisa toda. Aí eu procuro sempre apalpar, com a mão, para poder sentir um design, alguma coisa e dali eu vou criando aquela... entendeu? A minha imagem.

Podemos comparar o mapa mental de uma pessoa cega ao que Ingold (2007) chama de mapa rascunho. As linhas dos mapas rascunhos são formadas pelo refazer (re-enactment) gestual de jornadas efetivamente realizadas, de e para lugares que já são conhecidos por um histórico prévio de idas e vindas. As junções, separações, interseções dessas linhas indicam quais caminhos devem ser seguidos e quais podem fazer com que se perca, dependendo de onde você queira ir. São linhas de movimento. $\mathrm{O}$ caminhar da linha retraça seu próprio caminhar pelo terreno. $\mathrm{Na}$ entrevista com Camila podemos distinguir os traços dos seus movimentos, quando está fazendo o reconhecimento espacial de um lugar para posteriormente formar seu mapa-rascunhomental. Muitas vezes esse reconhecimento espacial pode ser feito com o auxílio de uma pessoa que enxerga.

Olha, geralmente a pessoa vai me dando dicas, assim, do caminho. Eu procuro sempre parede. E algum obstáculo que tenha que eu sei. Se eu vou por uma parede, geralmente salão tem vaso, ‘ó, aqui é o vaso', logo depois é uma porta ou então a segunda porta é um banheiro. Aí eu vou sozinha na segunda vez. Na volta eu percebo onde eu estou sentada, passou a porta, passou o vaso, passou a parede, calculo mais ou menos a distância e já sei mais ou menos, se tiver alguém sentado do meu lado, já sei que tem que passar por uma cadeira, fazer uma volta. Por isso 
que eu falo que a gente tem que ter uma memória muito boa, porque tudo o que a gente faz tem que ser memorizado.

Latour e colegas (2013) ressaltam dois significados que julgam completamente diferentes da palavra correspondência e que muitas vezes são confundidos quando se pensa na ideia de mapa. O primeiro, que os autores relacionam a uma interpretação mimética dos mapas, se baseia na semelhança entre dois elementos (signos no mapa e território, ou palavras e mundo), enquanto que o segundo, relacionado a uma interpretação navegacional dos mapas, enfatiza o estabelecimento de alguma relevância que permite à navegadora, por exemplo, alinhar diversos sinais sucessivos ao longo de uma trajetória. Os mapas mentais de pessoas cegas podem ser compreendidos na interpretação navegacional, uma vez que são formados a partir de uma conexão entre sequências de sinais e informações dessemelhantes que vão sendo adquiridas ao longo do percurso.

\footnotetext{
Você percorre um lugar de olhos vendados, se você tiver a mínima referência espacial, você consegue fazer uma imagem, um mapa mental. É óbvio que se você tiver que fazer isso sempre, você vai acabar pegando prática, certo? Quando chego a um lugar novo eu percorro o lugar para formar esse mapa, para eu poder ter independência de me locomover. (Dora)
}

Camila também ressalta esse aspecto da autonomia de movimento que advém do reconhecimento espacial e da formação de um mapa mental de um ambiente. Conta que a primeira vez que foi a um salão de festas de um amigo ele levava todos os deficientes visuais para conhecer o lugar assim que chegavam - aqui é onde tem cerveja, aqui você pode pegar comida, para ir ao banheiro vem por essa parede. Essa atitude ela considera o diferencial. Diz que a pessoa cega também sente necessidade de se mover e que se não tiver feito esse mapa mental fica mais difícil.

Se pensarmos a partir de Latour e colegas (2013), o reconhecimento de um espaço seria o ato de mapear um território de forma navegacional, com o objetivo de proporcionar mobilidade e independência a uma pessoa cega em um ambiente particular. Com a especificidade de que este mapa em geral não tem interface material, ele é mental, cognitivo, individual, construído a partir de informações adicionadas que vão formar uma imagem. Tátil? Visual? Dora acredita que não importa o formato, a informação é que é importante. 
No final das contas não faz muita diferença, se é visual ou se é tátil ou é não sei o quê, é só o suporte físico que você usa para representar aquilo. Porque na verdade a informação ela é informação, ela não é nem visual, nem tátil, nem auditiva, ela é cognitiva, é assim que eu entendo. É como você discutir se o disco no CD é o mesmo no vinil, é o mesmo no MP3. Isso é só o suporte, mas o conteúdo ele é o mesmo e está em suportes diferentes, não é? Então eu acho que é a mesma coisa, sabe? Mais ou menos, claro. É uma comparação, uma analogia. (...) Mapa é igual à imagem, está contaminado pelo visual. Na verdade mapa também não é visual. O mapa é a informação de como é aquele lugar. Aquela informação de como é a coisa espacialmente. $\mathrm{O}$ jeito melhor de representar é visual, mas às vezes você diz assim "vou dar o mapa de como vai na minha casa" e não é um desenho, é um monte de palavras, não é isso? "vai em tal lugar, vira em tal lugar, vai em tal rua"... não é assim? Então o mapa é uma informação. O que eu faço é uma coisa até parecida com o visual, só que o suporte que eu uso pode não ser exatamente visual, pode ser tátil. Você pode pensar num mapa mesmo, numa planta baixa, mas pensa que as linhas, em vez de serem um risco, são um relevo. Pensa com linhas em relevo, está aí um mapa mental de uma pessoa cega.

Tendo como inspiração o conceito de rizoma, elaborado por Deleuze e Guatarri (1995), pode-se pensar sobre a composição mental que pessoas cegas fazem de um ambiente e a relação que se coloca entre mapa e informação, dissociando-os de um suporte visual. Os autores comparam o rizoma a um mapa, que difere do decalque por estar inteiramente voltado para uma experimentação ancorada no real. Oposto ao grafismo, ao desenho e à fotografia, oposto aos decalques, o rizoma se refere a um mapa que deve ser produzido, construído. O mapa "é aberto, é conectável em todas as suas dimensões, desmontável, reversível, suscetível de receber modificações constantemente. (...) um mapa tem múltiplas entradas enquanto o decalque volta sempre ao mesmo" (Deleuze \& Guatarri, 1995: 22). O mapa mental de uma pessoa cega estaria, nesse sentido, mais próximo do rizoma do que do decalque, com informações que conformam entradas, linhas que são moldadas e se modificam a partir de direções e distâncias percorridas ou materiais experimentados.

Os mapas-rascunhos-mentais de pessoas cegas, como rizomas, não são cercados por molduras ou fronteiras. Consistem das linhas que o fizeram, nem mais nem menos. Linhas que são desenhadas ao longo, na evolução de um movimento, ao invés de atravessarem as superfícies nas quais são traçadas. Como nos mapas rascunhos de Ingold (2007), o conhecimento que se tem do entorno é forjado no curso mesmo de se mover através dele, na passagem de um lugar para o outro e nos horizontes em transformação ao longo do caminho. 


\section{Mobilidade em espaços urbanos - o acesso à cidade}

Desenvolverei a discussão do direito e do acesso à cidade a partir da questão do deslocamento e da mobilidade de pessoas com deficiência visual pela cidade do Rio de Janeiro. Os locais frequentados ou evitados, as dificuldades encontradas no percurso e as estratégias para superá-las, os usos que se faz do transporte público, a necessidade de ajuda na rua.

A escolha do percurso urbano, os locais visitados e os locais evitados ou desconhecidos, aparece pautada não só nas relações sociais estabelecidas em cada lugar, mas na maior ou menor familiaridade com as próprias ruas, seu trajeto físico e os estabelecimentos.

DaMatta (1985) ao analisar a sociedade brasileira e sua relação com o espaço, identifica a atuação de dois códigos sociais complementares e diferenciados, o código da casa, fundado na família, na lealdade, na pessoa e no compadrio, e o código da rua, o mundo exterior, mais rígido, baseado em leis universais e no formalismo. Estes dois conceitos desenvolvidos pelo autor podem nos ajudar a pensar os graus de proximidade ou distanciamento que aparecem nas entrevistas de pessoas cegas sobre os espaços urbanos que frequentam. Na entrevista com Jair, percebe-se que as ruas, os bairros e os lugares frequentados são divididos em conhecidos e desconhecidos. $\mathrm{O}$ conhecimento passa pela familiaridade com o local, com os elementos físicos que o compõe e que se tornam marcações de reconhecimento.

Na cidade os lugares que eu já andei, os bares que eu já parei, são os lugares que eu sempre vou, que as pessoas me conhecem. Paro, bebo alguma coisa, converso. (...) se vou numa rua que eu conheço, no caso vou lá em Botafogo, na rua São Clemente, aquela rua eu já conheço toda. Aí eu não preciso perguntar a ninguém, porque eu sei pra onde é, onde é que sai, ali eu conheço tudo. Em Copacabana, ali eu conheço, salto na Barata Ribeiro, vou andando e saio lá na beira da praia. Conheço, eu vou sozinho, entendeu?

O conhecido ou desconhecido aparecem associados para Jair a um sentido de orientação espacial, ao mapa das ruas que compõem um bairro. Conhecer para ele é sinônimo de autonomia, de andar sozinho e não precisar de ajuda. Mas Jair sugere ainda que o sentido de conhecimento de um lugar se dá não apenas por saber se localizar espacialmente, mas também pela familiaridade com as pessoas e os estabelecimentos frequentados. Os espaços conhecidos adquirem para Jair uma 
proximidade e uma intimidade que poderiam ser relacionadas ao conforto e a segurança da "casa", nos termos de DaMatta, mas que nesse caso podem ser melhor traduzidos pela ideia de vizinhança.

Park (1984) indica que, com o tempo, cada seção ou quarteirão da cidade carrega as características e qualidades de seus habitantes. Cada parte da cidade inevitavelmente se tinge com os sentimentos peculiares de sua população. $\mathrm{O}$ efeito disso, para o autor, é que aquilo que inicialmente era apenas uma expressão geográfica se converte em uma vizinhança, uma localidade com sentimentos, tradições e uma história própria.

O bairro onde Jair nasceu pode ser considerado como a sua vizinhança, no sentido dado por Park (1984), ali ele se sente inserido em uma rede local de solidariedade e intimidade, mas o próprio bairro onde mora há nove anos não adquiriu o mesmo contorno.

Nova Iguaçu, eu sou cria de lá, eu sou cria de Nova Iguaçu. Lá eu ando de olhos fechados, para qualquer lugar eu conheço, qualquer rua, te levo em qualquer lugar, porque eu sou cria de lá. Agora aqui... já vim morar aqui já cego. Tem 9 anos que eu moro aqui em Caxias.

O: mas você já se sente bem aqui no bairro, já conhece?

Ah, porque eu já conheço. Os lugares que eu costumo andar eu já... só esses lugares aqui tá bom, o caminho pra mim pegar a condução, o caminho que eu salto para pegar a outra condução, esses caminhos é beleza, porque eu já chego em casa tranquilo.

É interessante notar que o sentido de conhecimento e familiaridade dado aos espaços urbanos por Jair se coloca não apenas pelas relações de sociabilidade ali estabelecidas, mas também pelo domínio dos caminhos, do mapa daquele trecho ou mesmo do "trajeto" 2 percorrido para chegar e sair destas regiões. E esse domínio, tanto no seu caso quanto no caso de Angela, aparece relacionado a um momento anterior à perda da visão. O depoimento de Angela sobre a experiência de mostrar Copacabana para um amigo, também cego, é ilustrativo:

Agora mais ou menos há uns 3 anos, eu... você vai achar até engraçado, eu trouxe um outro cego para conhecer Copacabana, que ele não conhecia. (...) eu falei para ele que trabalhei muito tempo em Copacabana. Eu, quando enxergava, andava isso aí tudo e tal... aí ele disse "você seria capaz de ir a Copacabana só eu e você,

\footnotetext{
${ }^{2}$ Magnani (2002) define a categoria "trajeto" como referente a fluxos recorrentes no espaço mais abrangente da cidade, sendo a extensão e a diversidade do espaço urbano para além do bairro o que coloca a necessidade de deslocamentos por regiões distantes e não contíguas.
} 
só nós dois sozinhos?'. Eu digo 'sou'. "Você tem certeza que você vai saber onde você vai estar andando?'. 'Olha, certeza, certeza eu não sei, mas uma coisa eu garanto, perdidos nós não vamos ficar'. Aí pegamos o ônibus e descemos na Siqueira Campos. Cada rua que ia passando, que dava para eu reconhecer, porque às vezes eu distraia, ele falando comigo eu não sabia, né... aí quando entrou na Barata Ribeiro eu falei para ele 'olha, aqui, esse ponto aqui é da rua Belford Roxo, ali está a rua tal, aqui a sua esquerda está a ministro Viveiro de Castro, que é transversal, e tal'.

$\mathrm{O}$ : e você ia reconhecendo como?

Por memória anterior, entendeu? Do espaço. Quando nós descemos na Siqueira Campos ficou mais fácil, porque andando eu já sabia onde eu estava atravessando... eu fiz assim, entrando numa rua, fazendo os quarteirões em ziguezague, aí fomos parar na beira da praia. Foi uma coisa engraçada, que eu nunca tinha pensado em fazer, e ele ficou maravilhado, mesmo sem enxergar, ele se sentiu como se ele estivesse enxergando Copacabana inteira.

O sentido de proximidade e domínio de espaços urbanos frequentados antes da cegueira é transformado em distância e receio nos espaços que, ainda que visitados anteriormente, não adquiriram familiaridade. Na descrição de Jair sobre sua sensação ao andar por tais lugares mais afastados da sua vizinhança aparece a noção do espaço da rua "como algo movimentado, propício a desgraças ou roubos, local onde as pessoas podem ser confundidas com indigentes e tomadas pelo que não são" de que nos fala DaMatta (1985:50). A insegurança de Jair se refere ao desconhecimento tanto do espaço físico de um bairro, quanto aos seus usos e seus frequentadores.

Laranjeiras teve lugar que eu já andei, eu frequentava. Muitos amigos que trabalhavam comigo moravam nesse lugar. A amizade que eu fazia era fora de série, eles gostavam de mim para caramba.

O: mas você ainda tem contato com essas pessoas hoje?

Eu não tenho como, entendeu? Tentei até ir na casa dessa pessoa lá em Laranjeiras, aí eu não encontrei. Fiquei com medo de nego me informar lugar errado lá.

O: você tem medo de andar pelos lugares?

É, porque hoje em dia... porque tem muita gente que fala que acha que eu não sou cego. Aí às vezes estou andando em um lugar, não sei como é que é aquele lugar ali, às vezes é ponto de droga deles, eles acham que eu não sou cego, e aí? Vão fazer uma covardia como teve com aquele, o Tim Lopes, né? Poxa, tudo isso eu penso.

Como lembra Magnani (1996), pessoas em trânsito por um pedaço que não o seu costumam ser cautelosas. O conflito e a hostilidade estão sempre latentes já que qualquer lugar fora do pedaço é uma parte desconhecida do mapa e, portanto, é associada ao perigo. Essa sensação de insegurança aparece exacerbada em Jair pela sua situação atual da cegueira. 
A relação de maior conhecimento e proximidade de Jair e Angela com lugares da cidade anteriormente vistos trazem questões sobre memória visual e identidade, relacionadas ao espaço. Por ser marcado pelas relações estabelecidas entre os homens, Halbwachs (1990) indica que o espaço assume significados, sendo regido pelos mesmos símbolos que impregnam a vida social e se tornando ponto de referência na estruturação da memória. É significativa a metáfora de Jair, que diz que por conhecer tanto o bairro de Nova Iguaçu, bairro onde nasceu e passou boa parte da sua vida, pode andar por lá de olhos fechados. Os lugares, o bairro, já fazem tão parte do seu ser, os caminhos e as ruas já foram tantas vezes vistos e percorridos e, por isso, incorporados, que a visão não lhe faz mais falta para saber se localizar ali.

Lugares anteriormente frequentados por motivos de trabalho ou de lazer apresentam essa característica do conhecido, da segurança do caminho, dos estabelecimentos e construções que ali existem. Esse conhecimento anterior à perda da visão, a memória visual que têm destes espaços, contribui para uma maior mobilidade atual quando percorrem estes lugares, ao se deslocarem por seus trajetos.

Pollack (1992) considera a memória um fenômeno construído, onde os modos de construção podem ser tanto conscientes quanto inconscientes. Aquilo que a memória grava, recalca, exclui ou relembra seria o resultado de um verdadeiro trabalho de organização. O autor ainda destaca que a memória é um elemento constituinte do sentimento de identidade, na medida em que ela é também um fator extremamente importante do sentimento de continuidade e de coerência de uma pessoa em sua reconstrução de si. Nos depoimentos de Angela e Jair a respeito dos espaços vistos e dos novos espaços percorridos após a perda da visão e a relação de distanciamento e proximidade que adquirem, essas dimensões aparecem entrelaçadas à concretude dos bairros. O que está próximo, a relação de continuidade e coerência, é estabelecida com um lugar que está distante, tanto no tempo quanto no espaço. No caso de Jair, ele não morava mais na sua vizinhança há pelo menos nove anos. O seu sentimento de identidade atual em relação ao lugar também está relacionado a uma ideia de si mesmo enquanto alguém que enxergava e à maior independência que a visão possibilita nas relações de deslocamento e mobilidade urbana. Sua relação atual com o bairro onde mora, por outro lado, parece apontar para um distanciamento maior - seu domínio se restringe a entrada e saída, aos caminhos que cotidianamente percorre. 
Com o exemplo de Jair é possível perceber a conexão que a psicóloga do IBC coloca entre o tempo, o grau anterior de visão e a locomoção. Ela diz que quanto mais tempo a pessoa enxerga, mais essa memória poderá se transformar em um facilitador para a locomoção. Reencontramos novamente a restrição da mobilidade como uma das principais consequências da cegueira. Entretanto, como fica explícito no depoimento de Renata, o não ver nem sempre é a única ou a principal causa dessa restrição.

Eu creio que a maior dificuldade (com a cegueira) para mim em particular, não sei se é a maior dificuldade para todos os cegos, mas eu creio que sim, é a locomoção. É realmente complicado porque primeiro que as ruas são muito emburacadas, é muito complicado de andar, é muito violento. Tem um monte de carros parados na calçada e isso complica para andar. Tem gente de rua dormindo no chão, morador de rua. Também complica. Eu vou para lugares conhecidos sozinha. Por exemplo, eu venho para cá e vou para casa com tranquilidade, mas sei lá, me manda ir para um lugar que eu não conheço? Não sei se eu teria tanta coragem assim, sabe? A locomoção, para mim, acho que é a maior dificuldade.

O depoimento de Renata coloca em cena o aspecto urbanístico da cidade e o fluxo da vida urbana. A má conservação dos espaços e serviços públicos, a experiência da rua em sua materialidade e também nas relações sociais que ali se desenvolvem entre moradores, transeuntes, passantes, vendedores, tem impacto na liberdade de ir e vir de uma pessoa cega. Algumas vezes restringindo (no caso mencionado por Renata) e outras vezes ampliando sua mobilidade. Entraremos neste ponto a seguir.

\section{Infraestrutura urbana e deslocamento}

O uso da bengala é estritamente recomendado nos atendimentos de OM para o deslocamento de uma pessoa cega em centros urbanos, mesmo quando estão passando por uma região ou local familiar. Ainda que os caminhos sejam conhecidos estão em constante transformação. Um buraco, uma pedra, um desvio, qualquer coisa pode tornar estranho o que antes era familiar, colocando em risco a segurança pessoal no deslocamento. Camila diz que volta e meia precisa se lembrar de andar mais devagar, já que mesmo conhecendo muito um lugar tem que ter cautela porque alguém pode, de um dia para o outro, ter colocado algo no caminho. Dora acrescenta que a 
necessidade da bengala é também para que as outras pessoas ao redor percebam que ela não está vendo.

Jair fala que um dos seus maiores medos é de cair dentro de um buraco na rua. Poste e parede ele consegue perceber, mas buraco, se fizer a técnica do toque e a bengala passar por cima, quando completar a passada o pé pode ir direto no buraco. Ele nunca caiu, mas tem medo. Calçada com muito desnível também pode entortar o tornozelo. Com ele aconteceu uma vez e disse que por conta disso aquele lugar ficou marcado, não passa mais por ali.

Já Angela diz que, mesmo quando anda sozinha, nunca sentiu muita dificuldade no deslocamento para lugar nenhum. Fora algumas cabeçadas em orelhões, porque isso diz que é impossível não acontecer. Para ela orelhão é o maior inimigo da mobilidade urbana de cegos no Rio de Janeiro. A única vez que caiu estava acompanhada. Quase foi direto em um buraco de uma galeria aberta no meio da rua. Uma perna desceu, a outra ficou com o joelho dobrado na beirada. Foi a sua sorte. Dora acha que as condições da cidade do Rio de Janeiro deixam muito a desejar, ainda que visualmente possam ser boas. Para ela a relação com a cidade está de má qualidade. Considera uma cidade barulhenta, fedorenta, suja, todos os lugares sempre cheios de gente, engarrafada.

O grau de familiaridade com o local e o planejamento são elementos a serem considerados na hora de fazer um programa. Renata fala que antes de decidir se vai ou não a qualquer lugar precisa pensar na parte prática - o tipo de programa, a forma como vai, se o local é conhecido ou desconhecido, a hora que vai voltar, se é tarde da noite ou se não é. Ela própria diz que não costuma sair muito à noite, acha mais tranquilo andar durante o dia, ainda mais se estiver sozinha.

Todos esses aspectos mencionados pelos pesquisados nos levam a compreender um pouco melhor seus trajetos pela cidade, os empecilhos a serem superados, as estratégias elaboradas.

\section{Transporte público}

Além de táxi, Dora costuma se locomover também de metrô, mas evita pegar ônibus. Ela diz que já pegou muito ônibus na vida, tanto no Rio de Janeiro quanto em São Paulo, quando morou lá, mas acha que o serviço foi ficando cada vez pior. Os 
horários são irregulares, os ônibus demoram a passar, além do fato de que, para saber qual é o ônibus que está vindo e para fazer sinal para ele parar no ponto é necessário pedir ajuda para alguém. No interior do ônibus ela sente dificuldade na passagem estreita e espremida pela roleta. Acha que na maior parte das vezes os ônibus também vêm muito cheios. Cada um tem um layout diferente, os degraus são muito altos, ela nunca sabe onde ou em que altura está o ferro para se segurar. No Rio de Janeiro salta-se do ônibus pela parte de trás. Para ela isso é motivo de insegurança:

\begin{abstract}
Esse negócio de descer por trás eu acho que é muito mais inseguro, porque o motorista não está me vendo direito, eu não tenho certeza se ele está me olhando, eu gosto de descer na porta do motorista, porque eu gosto que ele veja quando eu acabei de descer. Porque eu posso não conseguir descer tão depressa, porque eu vou pesquisar com a bengala primeiro onde eu vou descer, se eu estou descendo em cima de um bueiro, se ele parou em cima de um buraco, em cima de uma água, então eu vou demorar mais, porque eu quero pesquisar isso, e aí eu fico com insegura dele arrancar.
\end{abstract}

Outro momento crítico na viagem de ônibus é saber se localizar em relação aos pontos, já que invariavelmente o motorista não para em alguns pontos ou para em lugares que não são pontos, o que dificulta. Beatriz diz que apesar de precisar usar constantemente, considera o serviço extremamente precário. Na cidade do Rio de Janeiro ela acha que não existe nenhuma gestão dos ônibus, os pontos não têm nenhuma estrutura, os motoristas não são educados, não são treinados, não tem nenhuma cultura nas empresas para se lidar com nenhum tipo de necessidade, seja ela permanente ou temporária. Comenta que qualquer um pode ter uma deficiência física ou sensorial temporária, pode ter quebrado o pé ou feito uma cirurgia no olho, por exemplo. A pessoa não precisa ser deficiente, pode estar momentaneamente deficiente e precisar daquele serviço da mesma forma. Em comparação com o deslocamento via ônibus o metrô seria mais vantajoso para a pessoa cega. Em relação ao momento de saltar, por exemplo, ainda que o áudio que alerta a chegada das estações não esteja funcionando ou esteja baixo, a pessoa pode contar o número de estações ou mesmo perguntar para os outros passageiros, já que as estações têm nomes.

O metrô seria o sistema de transporte público que, na opinião dos pesquisados, estaria mais preparado na cidade do Rio de Janeiro para atender uma pessoa cega. Ao invés de precisar pedir ajuda para alguém desconhecido, que pode não querer ou não saber ajudar, os funcionários do metrô recebem treinamento para embarcar um 
deficiente visual. Dora acha que faz muita diferença porque faz parte do serviço deles. Beatriz esclarece que o procedimento da empresa é o agente de segurança embarcar o deficiente visual e passar um rádio para onde ele está indo, informando que ele está a caminho e em qual carro, para que o agente da estação de destino o espere na saída. Ela diz que esse é o procedimento, mas que também tem falhas. Às vezes vem um funcionário correndo, se desculpando porque estava atendendo alguém do outro lado, e dizendo que o efetivo está pequeno. Dora fala que mesmo que eventualmente perca um metrô porque está esperando o funcionário aparecer, acha que é mais decente, mais respeitoso do que o serviço oferecido pelas empresas de ônibus, que é praticamente inexistente. Camila também elogia o investimento em acessibilidade do metrô. Para deficientes visuais, a empresa instalou pisos podotactil em todas as estações para indicar o caminho, fez marcações em Braille e com anéis no corrimão, para indicar ao deficiente visual o início e o término de escadas, além de mapas táteis em Braille que auxiliam no conhecimento da arquitetura da estação ${ }^{3}$.

Pedro sente saudades de dirigir automóvel. A cegueira diversificou bastante seus meios de transporte. Antes de ficar cego, ia para todo o lado de carro, agora tem que pegar trem, ônibus ou metrô. Disse que nunca tinha andado de trem na vida, passou a andar depois de cego. Beatriz acha o trem um dos meios de transporte mais perigosos para uma pessoa cega embarcar sem ajuda. As estações de trem não são padronizadas, em uma a plataforma está mais baixa, em outra a plataforma está mais alta, às vezes a distância do trem está próxima, outras mais distante. Acha perigoso para deficiente visual, mas também para idoso. Diz que nem sabe como um cadeirante faz para entrar e sair do trem. A Supervia, empresa que administra o transporte ferroviário no Rio de Janeiro, foi denunciada por organizações como o IBDD (Instituto Brasileiro dos Direitos da Pessoa com Deficiência) por não oferecer acessibilidade nenhuma em suas instalações, ainda que afirme que o assunto é prioridade em sua gestão ${ }^{4}$.

\footnotetext{
3 Para maiores informações sobre acessibilidade do metrô Rio ver o site da empresa: http://www.metrorio.com.br/acessibilidade.htm. Acesso em 19.02.2014.

${ }^{4}$ Ver matéria de 23 de outubro de 2012 em: http://www.ibdd.org.br/noticias/noticias-noti-114supervia\%20n\%C3\%A3o\%20acessivel.asp. Acesso em 19.02.2014.
} 


\section{O imperativo da ajuda}

Não é apenas no uso do transporte público, mas também no ir e vir a pé que a pessoa cega vive uma situação social corriqueira no cotidiano urbano da cidade do Rio de Janeiro: a de precisar pedir e receber ajuda de outros. Essa é uma dimensão bastante complexa que envolve situações de interação social e a necessidade de se contar com outras pessoas, que se transformam em vetores de deslocamento e mobilidade no espaço urbano.

Goffman (1966), que analisa o comportamento em locais públicos, aponta que uma das ocasiões que gera uma espécie de abertura para se iniciar um contato e uma comunicação entre dois indivíduos que não se conhecem é quando um deles está em necessidade patente de ajuda. Em situações como essa o autor coloca que os laços entre pessoas desconhecidas são sentidos como sendo suficientemente fortes para suportar a satisfação da ajuda voluntária, mesmo quando a pessoa que recebe o serviço é aquela que inicia o encontro. A trivialidade dessa situação no dia a dia de uma pessoa cega que se desloca por ruas de uma grande cidade não a torna menos complexa. Renata fala da inevitabilidade desse pedido de ajuda, especialmente na locomoção. Diz que não tem outro jeito, não tem como fazer diferente porque não dá para pegar ônibus sozinha ou atravessar a rua sem ajuda.

Goffman indica que um encontro geralmente se inicia com alguém que realiza um movimento de abertura, tipicamente por meio de uma expressão especial com os olhos, mas que algumas vezes também pode ser um pronunciamento ou um tom especial de voz no início da fala. O engajamento só se inicia quando essa abertura é reconhecida pelo outro, que sinaliza de volta com seus olhos, voz, ou de alguma maneira marcando que se coloca disponível para o outro para propósito de uma atividade mútua. Na ausência do olho no olho, a Terapeuta Ocupacional (TO) que realiza os atendimentos de OM diz que o som ou a voz passam a ser o instrumento principal de comunicação de uma pessoa cega na rua. Se quem enxerga se comunica por um olhar ou por um gesto no cotidiano urbano, o deficiente visual usa a voz, a fala. Ela insiste com a reabilitanda que atende que ela precisa falar para que uma pessoa que estiver próxima tenha alguma reação e ela ouça. Simula um pedido de ajuda: "bom dia. Alguém poderia me ajudar a chegar até a estação de trem de Japeri?”. Se ninguém responde, deve falar de novo. Quando alguém aparece, repetir a 
pergunta enfatizando o "até", que é para não ser largada no meio do caminho. Sugere que ela se recorde dos cegos que viu quando enxergava. Reforça que eles falam, que alguns são mais abusados e batem com a bengala no chão. Cada um com a sua estratégia, mas verbalizar, comunicar, expressar o pedido de ajuda é fundamental.

Camila conta que quando tem que atravessar uma rua pede em um tom de voz médio “alguém me ajuda, por favor?". Diz que tem muita sorte, porque geralmente quando faz esse pedido sempre tem alguém por perto que pergunta o que ela quer. Tanto ela quanto Caetano acham que as pessoas hoje em dia estão se habituando a ver deficientes visuais na rua.

Algumas das questões presentes nessa necessidade de ajuda no deslocamento de uma pessoa cega em um contexto urbano envolvem a possibilidade de uso de técnicas ou posições corporais específicas que facilitam a condução; estratégias para pedir auxílio; a conversa que se tem ao longo do percurso; mal-entendidos, equívocos e imposições.

\section{Quando a ajuda atravessa - equívocos ou imposições}

A ajuda que se recebe não é plana, existem graus variados de necessidades e tipos de ajuda, de acordo com o objetivo final, características específicas da pessoa que pede ajuda e de quem oferece, se está a pé ou qual o meio de transporte utilizado. São duas coisas muito distintas contar com o serviço prestado por um profissional treinado ou contar com a voluntariedade da ajuda alheia. Essa última nem sempre cuidadosa. Dora diz que com ela e com outras pessoas cegas que conhece já aconteceu algumas vezes de ser encaminhada para o ônibus errado. Quando isso ocorre, existem formas mais ou menos drásticas de descobrir. Às vezes, por uma intuição ou o que chamou de sexto sentido, vai lá e confere com o trocador ou com um passageiro a numeração do ônibus. Outras vezes, quando o veículo faz a primeira curva errada e a pessoa cega está atenta, descobre que aquele não era o ônibus que queria. Ou então descobre quando já é tarde demais e o erro vai custar para ser remediado.

Beatriz relata uma segunda vivência de ajuda atravessada, que procurarei descrever de uma perspectiva de situação social, conforme colocada por Goffman (1966). O autor entende situação social como uma arena física qualquer na qual a 
pessoa que entra se encontra exposta à presença imediata de um ou mais outros. No nosso caso a arena é o espaço público da rua, um determinado percurso no centro da cidade do Rio de Janeiro.

Beatriz saía de uma imobiliária que se localizava no início da Av. Rio Branco, perto da Praça Mauá. De lá precisava ir até uma loja na Rua da Alfândega. Como não sabia onde ficava o ponto de ônibus, e também achou que a distância não era tanta, era só seguir e atravessar a Presidente Vargas, se decidiu por ir a pé. Começou a andar. Sem avisar ou sem perguntar se ela precisava de ajuda, um sujeito se aproxima, dá as mãos a ela segurando firme e começa a andar colado, como se fossem namorados. Depois de alguns passos caminhando desse jeito ele pergunta pra onde ela vai. Ela responde que está indo pra um pouco depois da Presidente Vargas. Ele atravessa a primeira rua com ela. Quando chegam ao sinal da Presidente Vargas, estava aberto para os carros. Eles param na faixa de pedestres e ela fala "amigo, já está legal já, não precisa ir não, daqui dá pra eu ir tranquilo". Ele responde "fíca quietinha aí que eu já falei que eu vou te levar”. Beatriz diz que nessa hora pensou “F... e agora?". Continuou andando e pensando como ia fazer para se livrar daquele sujeito. Chegaram do outro lado, atravessaram as quatro pistas da Av. Presidente Vargas e estavam andando pela Av. Rio Branco. Ele então desce o meio fio e faz menção de atravessar a Rio Branco com ela. Nesse momento ela estanca firme e fala alto: "eu não vou atravessar". Tenta desvencilhar sua mão da mão dele. Ele não diz nada, mas colou de novo com ela segurando forte em sua mão e continuam andando. Quando chegam em frente à Rua da Alfândega ela para novamente e uma terceira pessoa se aproxima, um homem, que pergunta “a senhora quer alguma coisa?". Ela aproveita que alguém falou com ela e se despede novamente do primeiro sujeito “amigo, muito obrigada, valeu mesmo, aqui está bom”. Nessa hora ele larga a mão dela, ela então rapidamente se despede dos dois homens e segue adiante. Logo a frente ela repara que o segundo homem que a abordou estava vindo atrás dela. Ele se apresenta, diz que é policial e que tinha sido uma quarta pessoa, um senhor, que viu aquela situação de longe, achou estranho e avisou a ele. Falou que o sujeito que a abordou era um cara esquisitíssimo que inclusive ainda estava na rua, não tinha ido embora. O policial então espera ela resolver o que precisava na loja da Rua da Alfândega e depois a conduz até o metrô. 
As interações sociais que ocorrem nos espaços públicos da rua fornecem materiais que possibilitam entender um pouco melhor as categorias e posições sociais que entram em relação nessas situações. Esses momentos de imposição da ajuda explicitam a vulnerabilidade a que pessoas com deficiência visual estão expostas em seu cotidiano. A forma de abordagem do sujeito a Beatriz já em um primeiro momento infringe as regras de conduta ou as convenções sociais de cortesia. Ela dá alguns sinais de desconforto e insatisfação com o encontro. Primeiro de maneira educada, utilizando expressões verbais adequadas que indicam querer finalizá-lo. Em seguida de forma mais direta quando tenta puxar a mão ou quando se recusa a atravessar falando em tom de voz alto. Seus sinais são percebidos por alguém de fora que compreende a situação e aciona um terceiro elemento, um policial, que além de também ser homem é capaz de interferir por estar em uma posição social superior de autoridade.

Como lembra Goffman (1977), onde quer que um indivíduo esteja ou vá, sempre leva seu corpo com ele. Isso significa que qualquer que seja o mal que seu corpo possa fazer, ou estar vulnerável a, isso também vai junto com ele. O autor distingue vulnerabilidades de dois tipos: riscos impessoais - fogo, objetos que caem, batidas acidentais, etc.; riscos sociais, que são vistos como produtos de más intenções - roubos, assaltos, importunos, insultos verbais, assédio sexual. Estando na presença de quem quer que seja, o indivíduo o coloca vulnerável e se coloca vulnerável dessas mesmas formas. Alguns dispositivos de controle social procuram assegurar arranjos pelos quais um indivíduo não cause nenhuma dificuldade a outros e nenhuma dificuldade seja causada a ele. A lei é um desses fatores, outro seria a desaprovação e condenação moral por testemunhas do ato, o que de certa forma é o que ocorre na situação de Beatriz que descrevemos.

Goffman (1977) considera especialmente as diferenças de gênero e a situação das mulheres quando o assunto é a vulnerabilidade nos espaços públicos, concluindo que as mulheres estão, de uma maneira crônica, muito mais vulneráveis a sofrerem avanços impróprios nestes espaços. No caso que descrevemos a vulnerabilidade a riscos sociais como violência física ou assédio sexual é dupla, pela questão de gênero e pela deficiência visual que traz consigo o imperativo da ajuda. Por ser tão necessária no cotidiano da pessoa cega ela também a expõe a uma espécie de abertura, mesmo 
que involuntária, para a possibilidade de a qualquer momento ser abordado sob essa máscara do auxílio, seja esta a real intenção da abordagem, seja um disfarce.

\section{A ajuda como vetor de navegação em territórios urbanos}

Podemos encarar a ajuda no deslocamento como pontos ou paradas provocadas pelo trajeto, nesse ir e vir nômade de pessoas cegas. Mais do que linhas que conectam um ponto ao outro, a ajuda é vetor de re-territorialização. Uma direção, outras vezes uma mudança de direção. O espaço vai sendo costurado, o território vai sendo vencido, graças a essas operações locais, a esses acontecimentos ou afectos. Um espaço de distâncias a serem percorridas, percepções feitas de sintomas ou avaliações, mais do que medidas e propriedades. Se o que cobre o espaço estriado é o céu como medida, e as qualidades visuais mensuráveis que derivam dele, o espaço liso de navegação de pessoas cegas é ocupado por intensidades, ventos e ruídos, forças e qualidades tácteis e sonoras (Deleuze e Guatarri, 1997).

A ajuda na rua pode ser dada ao longo do deslocamento, para conduzir até um local específico ou atravessar uma rua; pode ser o aviso da chegada de um ônibus, mas também pode ser um direcionamento. Camila conta que perto do metrô de Botafogo tem um local em que camelôs montam barraquinhas ou colocam coisas no chão para vender. Ela vem com a bengala, alguém percebe que está se aproximando e vai atravessar o espaço da barraca e então ela escuta uma voz que a direciona: 'ó, por aqui' ou então 'mais para a direita'. O rapaz que trabalha em um estande de plantas sempre ajuda: - 'pra direita um pouquinho, agora pra esquerda, isso, agora pega a reta'. Ela agradece e segue adiante. Conta um episódio que aconteceu e que, segundo ela, foi também um sinal de que estava se recuperando do luto pela cegueira.

Ali eu notei que eu tinha me recuperado mesmo, me reabilitado. Porque eu tinha horror de me chamarem de ceguinha, eu me chocava, me magoava. E eu estava lá em Madureira, vindo na calçada com a minha bengala e aí um camelô lá do outro lado gritou - 'ceguinhaaaa'. Aí eu parei na hora. Eu estanco na hora. Aí eu fiquei parada, vendo o quê que ele queria falar para mim - 'ó, na sua frente tem obra'. E eu - 'é? E aí, como é que eu faço?', - 'quebra pra direita, agora vai, segue, isso...', aí me direcionou. E eu - ‘muito obrigada, tá? valeu', ele ‘que nada...'. Aí eu pensei gente se ele tivesse me chamado de ceguinha há um ano atrás eu ia cair assim em prantos na rua. Naquele dia eu falei estou bem legal mesmo, to passando no teste. 
Camila diz que hoje em dia vai para todo o lado sozinha e que para isso conta muito com essa ajuda das pessoas que direcionam o seu caminhar, moldam os desvios e as mudanças de direção na sua trajetória. Acha que em geral as pessoas estão sempre dispostas a ajudar.

Nem todos os vetores de navegação que aparecem levam para os caminhos inicialmente imaginados. Vimos os casos de equívocos ou de ajudas impostas. Negar uma ajuda que não é necessária a uma pessoa que insiste em ajudar nem sempre é uma tarefa fácil. Muitas pessoas tomam a negação como uma ofensa ou ingratidão da pessoa cega. Caetano diz que acontece muitas vezes das pessoas o pararem para ajuda-lo e ele não estar procurando ajuda. Nessas horas costuma responder "olha, não há necessidade aqui, mas obrigado, dá para eu ir" ou "estou esperando alguém aqui”, algum tipo de desculpa. Nunca fala de forma agressiva, para a pessoa não se sentir ofendida. Ele conta que conhece pessoas cegas que preferem não ser ajudadas, a não ser quando realmente precisam. Segundo ele, são pessoas que acham que ser independente é não aceitar a ajuda de ninguém. Ana fala em sua entrevista da preocupação em agradecer a oferta de ajuda, mas gentilmente negar quando ela não é imprescindível ou quando vai interferir no itinerário da pessoa que ofereceu.

\begin{abstract}
A moça vinha no sentido contrário, simpática a moça, 'oi, tudo bem? você precisa de ajuda?', eu falei assim 'você está indo para o mesmo lugar que eu?', 'não', eu falei 'você estava vindo de cá, não estava?', 'tava', eu falei 'então, se você estivesse vindo do mesmo lugar ou estivesse indo na mesma direção eu ia aceitar a sua ajuda, porque eu acho que não é nada, não faz mal a ninguém, muito pelo contrário, anda mais rápido, mas se você está indo para lá, não se preocupa não que eu conheço o caminho', 'ah, então tá bom', ela não ficou chateada e eu não recusei ajuda, mas eu acho sacanagem, eu conhecendo o caminho, tirar a moça do destino dela, eu acho que é meio... que é um pouco de exploração. Se eu não conheço eu digo assim 'bom, eu não conheço o caminho, se você puder me ajudar eu aceito ajuda', mas se eu conheço, ai meu Deus eu acho que isso é falta de... todo dia você não vai ter uma moça ali para ajudar.
\end{abstract}

Esbarramos aí em um limite imaginário e fluido entre o imperativo da ajuda será necessário contar com ela para atravessar certos itinerários urbanos, especialmente os menos conhecidos - e a dependência - não se deslocar para lugar nenhum sem ajuda. Cada pessoa parece lidar com essa necessidade de auxílio de maneira particular, e cada um vai desenhando esses limites nas situações pontuais e imediatas do dia a dia, como essa que Ana nos conta. Para ela, se transformar em linha de fuga do itinerário de alguém, que por sua vez se transformaria em vetor de 
navegação para o seu, numa situação específica de um percurso territorializado, já conhecido, ela considera exploração. A exploração traz para ela uma dupla consequência. Significa abusar da disponibilidade da ajuda alheia quando não é necessária e significa o risco de se acostumar tanto com essa "bengala" humana para sua mobilidade que, num momento em que ela não exista, sua ausência possa se transformar em imobilidade.

Assim como Ana, Caetano diz que mesmo quando não precisa, por já dominar determinado território, costuma aceitar a ajuda de quem oferece, no caso da pessoa estar indo para a mesma direção que ele. Possivelmente pelo mesmo motivo de Ana: estar acoplado a um vetor de navegação costuma aumentar a velocidade do andar. Mas Caetano conta que acontece de às vezes também mudar os seus planos por que surgiu uma ajuda que ele chama de "direta".

Eu ia fazer uma coisa, mas como pintou uma ajuda direta... tipo assim, eu estou na central, aí vou pegar ônibus na rodoviária lá atrás, mas eu ia passar numa loja ali pra ver um negócio. Mas aí a pessoa 'vou para o terminal, vai pra lá?', se não é muito necessário aquilo que eu ia ver na loja eu aproveito a carona e vou. Claro, deixo a outra para depois, para amanhã. Se for urgente eu vou fazer o que for mais necessário naquele momento, mas se não era tão urgente...

E assim os territórios urbanos vão sendo conquistados, com mais ou menos esforço, com maior ou menor familiaridade, mudanças de orientação, mais ou menos necessidade de auxílio. Como esse vetor de navegação não é um GPS, mas um ser humano, afectos emergem da interação. Ir a um lugar novo é uma decisão que demanda preparação anterior e determinado estado de espírito, desejar bons encontros que guiem o caminho e contar com a sorte. Camila descreve uma das primeiras vezes que decidiu se aventurar a chegar até um local desconhecido sozinha. De seu depoimento emergem os vetores de navegação que atravessaram seu caminho e essa espécie de sinergia entre seu desejo, seu humor e aquilo que encontra no percurso.

Tinha um aniversário em Campo Grande. Aí eu 'não vou não, ah, não vou sabe'. Aí eu estava em casa, 'ah, eu vou'. Liguei para a menina, 'como é que eu faço para chegar aí?', aí ela 'tu vem mesmo?', ficou toda feliz, 'eu vou', 'tu vem nada...', 'vou sim, como é que eu faço para chegar aí de Madureira?', falei logo onde eu morava, 'você pega tal ônibus, aí solta em Campo Grande, pega a Kombi Salim'. Aí fui e me arrumei. Sabe quando você respira fundo - 'eu vou'. Fui para o ponto. Cheguei no ponto e eu 'por favor, alguém pode ver o ônibus tal para mim?'. Antigamente eu tinha horror assim de... achava que eu estava ocupando alguém, hoje em dia eu tenho mais facilidade, ainda falo assim 'olha se o seu vier antes, não tem problema, eu peço para outra pessoa', pra não ser um... aí eu 
peguei o ônibus. Nisso... quando você está bem, você se determina, as coisas vão se encadeando direitinho. Eu entrei no ônibus, o motorista era maravilhoso e o trocador também. Aí o trocador 'passa, senta perto de mim, você vai para onde?', aí eu 'Campo Grande', 'Campo Grande... vamos fazer uma viagem longa', sentei. Estou indo, 1 hora, estou indo, 1 hora e meia, eu 'gente eu to indo para onde?', aí ele olhava pra mim, ele virava e dizia assim para mim 'ó, ainda não chegou não tá? já, já você vai estar chegando lá. Prá onde você vai?', aí peguei o papel, dei na mão dele, aí ele 'ah, você vai soltar no salim, tal e tal', que a menina tinha me dado um mapinha aqui no Benjamin. Quando chegou ele 'ó, tá chegando... chegou hein'. Aí eu 'tá bom, muito obrigada', aí ele 'peraí um instantinho, fulano ce vai ali pro Salim? Vai pegar a Kombi?', 'vou', 'acompanha ela pra mim?', me acompanhou até a kombi. Eu fui. Quando chegou na Kombi 'moço, você conhece uma menina...', ela falou assim 'conversa com ele que ele vai me conhecer, eu pego sempre', que ela mora lá e está sempre aqui (no IBC), 'conheço... pode deixar, eu te levo lá'. Gente as coisas foram assim, encadeando direitinho, aí isso vai te dando mais força, sabe, quando as coisas... mas aí eu botei uma coisa na minha cabeça, que tem dia, nem sempre as coisas fluem assim. E nesse dia que as coisas não fluem, você tem que ter muita paciência. Aqui o pessoal usa muito assim 'matar um leão por dia', que é a força que você tem que ter de levantar e sair. De estar sempre assim pedindo, 'tomara que tenha alguém legal por perto', que possa te ajudar, e se não for legal também que pelo menos 'quer atravessar?', aí atravessa, entendeu? E assim a tua vida vai.

Desejo que produz, é criativo, agencia elementos, cria territórios (Guatarri e Rolnik, 1996). Pessoas cegas em circulação contam com esses vetores de navegação para trilhar e traçar seus caminhos nos itinerários urbanos. As ajudas são formas de territorialidade que se revelam na instantaneidade e no acaso dos encontros. Cruzar a cidade e ir para um aniversário em um bairro distante é um movimento de desterritorialização e construção de um novo território para Camila. Para chegar lá ela conta com esses vetores, forças, linhas de fuga que atravessam, pontos entre duas linhas que não podem ser assinalados (Deleuze e Guatarri, 1997).

Uma história vivida por Beatriz nos dá mais elementos para entender a distribuição desses vetores no espaço aberto da cidade. A frequência com que aparecem ocorre ao longo de um percurso urbano, conforme as mudanças de direção e as casualidades que acontecem. Como alertam Deleuze e Guatarri (1997), a cidade, espaço estriado por excelência, pratica espaço liso por toda a parte. A ligação de um território com o seguinte não está definida e pode ser feita de uma infinidade de maneiras.

Eu trabalhei na Embratel um período de madrugada. Começava a trabalhar meia noite. Ali na nossa senhora de Copacabana eu pegava o 474, porque é o único que vem pela pista do canto, que eu já descia na calçada da Embratel e não precisava atravessar. Aí peguei o ônibus e pedi ao motorista, 'moço, você me deixa ali em frente ao prédio da Embratel', 'tá bom', ele saiu da praça XV, entrou na Presidente Vargas, tá andando, tá andando, eu falei 'gente esse homem... passou 
moço?', 'não, não passou não'. Antigamente, não sei se ainda está lá, tinha um outdoor da Embratel com a Ana Paula Arósio, ele achou que era lá. Eu falei moço 'para, para que eu vou descer', 'vai descer aqui?', 'vou, vou descer aqui, ué, vou para onde? Vou para o Jacaré?'. Eu não tinha noção de onde eu estava, em que altura da Presidente Vargas. Ele parou, abriu a porta e eu desci. Meia noite. E era um fim de semana, não tinha uma alma viva no centro. Respirei. Falei bom, começar a voltar, né? Não tinha noção da distância que eu estava. Olivia, por Deus, por tudo o que é mais sagrado, eu não sei até hoje o que aconteceu, surgiu uma criatura e ela veio do meu lado direito, ou seja, então ela veio da pista. Trocou duas palavras comigo, tipo 'vai para onde?' 'eu te levo', eu não lembro, foram duas palavras só, eu sei que ele deixou eu segurar no braço dele, eu estava depois da central. Eu não lembro do trajeto até a Embratel. Eu lembro que eu tentei puxar algum assunto e ele não respondeu, e assim, são flashes, eu lembro muito vagamente... e de madrugada a gente não usava as recepções normais, a gente entrava pela garagem, os seguranças ficavam ali na garagem, e a garagem dá ali pra onde tem a saída do metro da Presidente Vargas, na Regente Feijó. Aí quando eu cheguei assim perto, quando eu fui me aproximando da garagem da Embratel, que eu comecei a ouvir as vozes dos seguranças o cara sumiu. Palavra de honra. Uma coisa impressionante. Incrível. Impressionante mesmo. Nunca esqueci isso.

A ajuda, ao mesmo tempo em que é um elemento que promove a ampliação e o domínio de territórios, também restringe a possibilidade de circulação de pessoas cegas pelo espaço urbano. Não só nos momentos em que as coisas não fluem, nas palavras de Camila, em momentos em que ela não é bem-vinda, como na situação vivida por Beatriz ou em outros em que acaba levando para territórios indesejados, como nos casos de ônibus errado mencionados por Dora, mas também quando essa ajuda é escassa ou inexistente.

Nessa última história contada por Beatriz, o equívoco do motorista a coloca em uma situação de extrema vulnerabilidade - tarde da noite, final de semana, Av. Presidente Vargas. A ajuda que vai ao seu encontro a seguir parece um acaso tão improvável que a faz introduzir o relato dessa experiência com o dizer "anjo da guarda de cego não dorme em serviço”.

Não andar pela rua à noite não é somente uma questão de prudência pela (in)segurança urbana relacionada à violência ou medo de assalto, por exemplo, que seriam motivos para menor circulação de qualquer pessoa mais preocupada em se precaver numa cidade grande, mas no caso de pessoas cegas também está diretamente vinculada à menor possibilidade de navegação devido à menor oferta de ajuda. Menos pessoas, menor chance de ser ajudado. Se uma pessoa cega não tem a possibilidade financeira de contratar um motorista ou pegar um táxi, seu ir e vir se restringe ao trem ou metrô, formas mais estriadas de deslocamento, mas com horários e destinos restritos, ou ao ônibus urbano. O trem e o metrô param de funcionar a partir de 
determinado horário. O ônibus muitas vezes circula a noite inteira, mas para uma pessoa cega utilizar esse tipo de transporte é preciso contar com a vetorização humana que costuma ser mais rara nos horários noturnos ou em dia de domingo, por exemplo. Nas palavras de Beatriz:

Eu evito sair de casa dia de domingo porquê... bicho, quase não tem pessoa na rua. Aí chega no ponto de ônibus não tem ninguém. Você fica ali parada no ponto de ônibus um tempão, os ônibus só passando, passando, passando... dá vontade de sair fazendo sinal para todos, né? o que te interessar você entra. Mas nem assim rola, porque você pode fazer sinal e ele parar lá na frente, o cara vai... é impressionante. Você está sempre realmente dependendo do outro, não tem jeito.

Goffman (1977) acredita que há duas categorias desvantajosas de indivíduos no contexto social urbano: aqueles que podem e tendem a se confinar em famílias inteiras e vizinhanças, e aqueles que não. Para o autor, no cenário americano, por exemplo, os negros são exemplos da primeira situação, deficientes, da segunda. Se pensarmos no acesso à cidade do Rio de Janeiro, pessoas cegas entrariam nessa categoria de pessoas que estão em desvantagem de Goffman, mas que não estão segregadas espacialmente. A segregação acontece pela menor possibilidade de circulação, pela inexistência de acesso autônomo para uma pessoa cega aos únicos serviços de transporte público que circulam em muitos pontos da cidade, os ônibus. A oferta de ajuda também varia de acordo com os turnos, alterando também a disposição das pessoas em ajudar. Caetano fala sobre essa mudança de estado das pessoas que circulam durante a noite:

A noite já começa a ficar complicado (encontrar ajuda) porque tem menos gente na rua, as pessoas estão mais apressadas, sei lá, as pessoas andam com medo também... por exemplo passa uma mulher sozinha, às vezes você é parado num lugar, ela não vai parar, principalmente se você não tiver assim bem claro que é deficiente visual, mas também as pessoas podem aplicar golpe por aí. As pessoas desconfiam de tudo e de todos né? A noite é sempre mais perigoso, as pessoas tem medo de se expor, de correr risco. Então já anda com pressa, já andam correndo.

Perlongher (2008) contesta as premissas espaciais de identidades fechadas, homogêneas, unificadas, refletindo sobre a ideia de território marginal. No estudo desenvolvido pelo autor, a relação dos michês com certos códigos sociais que se apresentam nos espaços da cidade é que vai contribuir para a construção de territórios subjetivos, atribuindo categorias a seus corpos e desejos em movimento. É pelo 
método da cartografia que o autor analisa essa produção de territórios que não se firmam em uma fixidez espacial. Se pensarmos com Perlongher, a territorialidade flutuante de cegos está na mobilidade e nos olhos das pessoas anônimas que os ajudam nas ruas, vetores de fixação de territórios e navegação no espaço urbano.

Park (1984) indica que a mobilidade de um indivíduo ou população em um contexto urbano deve ser medida não apenas pela mudança de lugar, mas pela variedade de estímulos para locomoção aos quais o indivíduo responde. Urry e Büscher (2009) propõem a instituição de uma ciência social onde o movimento, o movimento em potencial e o movimento bloqueado, assim como as imobilidades voluntárias ou temporárias, as práticas de habitação e a construção de lugares nômades sejam concebidos como constitutivos das relações políticas, sociais e econômicas.

Pensando nas trajetórias e linhas traçadas por pessoas cegas a partir do exercício de deslocamento e dos relatos que percorremos, é possível avaliar os fatores que concorrem para a redução ou ampliação de sua mobilidade. Atravessar a cidade diariamente faz parte da rotina de Caetano e de muitos frequentadores do IBC, mas para isso, nas palavras de Camila, é preciso "matar um leão por dia". O leão que se mata é a ineficiência de transportes públicos, a infraestrutura precária de ruas, calçadas, sinalizações, a desordem urbana, contar com a voluntariedade e o acaso de ajudas alheias que por vezes podem conduzir a lugares indesejados. No caso de pessoas cegas a segregação acontece por essas barreiras que dificultam sua livre circulação pela cidade. Para ir e vir precisam contar com as pessoas, que se tornam vetores de acesso aos lugares. Um local ermo, desconhecido ou em um horário em que há menos gente transitando restringe sua mobilidade e o seu acesso aos espaços urbanos.

\section{"A Urca é o paraíso dos cegos"}

Ainda que fundamentalmente móvel, os fluxos por determinados locais também podem promover a fixação de um território, a transformação e a apropriação de certos espaços em que os sujeitos passam a se sentir em casa (Guatarri e Rolnik, 1996). É interessante notar que a assiduidade de pessoas cegas ao bairro da Urca, nos arredores do IBC, também tem como efeito a transformação das relações de interação e 
sociabilidade de moradores, trabalhadores ou frequentadores do bairro com pessoas cegas. O convívio e a troca cotidianos como facilitadores de uma maior integração de pessoas cegas na experiência urbana daquele bairro. Essa relação é explicitada em mais detalhes por Camila, quando fala sobre um dos estabelecimentos que costumam frequentar para almoço nas cercanias do IBC.

\begin{abstract}
A Urca é o paraíso dos cegos. Porque na Urca todo mundo sabe tratar um cego, porque o Instituto é aqui, porque a gente anda muito pela Urca, almoça, o pessoal sai daqui e almoça num.... não é restaurante não, um barzinho que tem ali, aí eles sabem. Eles sabem que a gente não se serve, eles já dividem nos pratos, entendeu? O garçom toca em você... já conhece todo o método. Então todo mundo queria morar por aqui porque sabe que vai chegar num lugar e 'senta aqui, esse lado ó, o seu copo está à sua direita', esse tipo de coisa. Aí tem uma pessoa que falou assim 'gente, a gente tem que sair mais para outros lugares', ocupar, porque aí as pessoas vão aprendendo, a gente vai se sentindo melhor e as pessoas mais à vontade de tratar assim. Porque tem pessoas que tem inibição de chegar perto né, porque é isso, ela não sabe.
\end{abstract}

Estratégia de ocupação de bairros pelo comparecimento constante. Modificação das relações de interação de cenários urbanos pela presença e permanência. Algo que, na fala de Camila, demanda certo esforço coletivo, insistência e continuidade. Park (1984) sugere que além de uma organização física, a cidade também tem uma organização moral, se enraizando nos costumes e nos hábitos das pessoas que a habitam. Esses dois aspectos, físico e moral, estão em interação de maneira que moldam e modificam um ao outro. De certa forma a frequência e a circulação de cegos gerada pela localização do instituto promove a ocupação e territorialização do bairro por pessoas cegas, adaptando hábitos e costumes em restaurantes locais, por exemplo, que atendem essa clientela. Se inscreve inclusive na estrutura física do bairro, como no único sinal sonoro da cidade que foi instalado em frente ao IBC, no piso tátil que conduz do ponto de ônibus à entrada e saída do instituto ou no desnível em relevo que atravessa a calçada oposta ao instituto, autorizado pela prefeitura, que para cegos é uma sinalização que indica a aproximação do outro ponto de ônibus.

Magnani (1994) lembra que as decisões relativas ao uso do espaço no contexto urbano devem levar em conta a diversidade dos seus habitantes, não podendo ser tomadas em função de uma única lógica que supostamente decide o que é bom, conveniente e bonito para a cidade. Seria necessário considerar os pontos de vista decorrentes da existência de diversos atores sociais com suas tradições, modos de vida ou hábitos igualmente legítimos. 
O pleno exercício desse direito para pessoas cegas, ainda que previsto na Lei da Acessibilidade $^{5}$, que garante o direito de eliminação de barreiras arquitetônicas, de disponibilidade de comunicação, de acesso físico, de equipamentos e programas adequados, de conteúdo e apresentação da informação em formatos alternativos, é, entretanto, uma realidade ainda distante no contexto urbano do Rio de Janeiro. As iniciativas que começam a existir para deficientes visuais ainda se restringem a certos eventos, dias ou horários específicos ${ }^{6}$ ou estão circunscritas a locais restritos de uma área muito mais ampla ${ }^{7}$.

\section{Referências}

BAVCAR, Evgen. A luz e o cego. In: Catálogo O Ponto Zero da Fotografia - Evgen Bavcar. Rio de Janeiro: Very Special Arts do Brasil, 2000.

BRASIL. Ministério da Educação. Programa de Capacitação de Recursos Humanos do Ensino Fundamental: deficiência visual vol. 1, 2 E 3 / Marilda Moraes Garcia Bruno, Maria Glória Batista da Mota, colaboração: Instituto Benjamin Constant. Brasília: MEC, SEESP, 2001.

BRASIL. Ministério da Educação. Orientação e Mobilidade: Conhecimentos básicos para a inclusão do deficiente visual /Elaboração Edileine Vieira Machado... [et al.]. Brasília: MEC, SEESP, 2003.

CALVINO, Ítalo. As cidades invisíveis. São Paulo: Companhia das Letras, 2002.

CASEY, Edward S. How to Get from Space to Place in a Fairly Short Stretch of Time. In: FELD, S. \& BASSO, K. (orgs.) Senses of Place. Santa Fé: School of American Research Press, 1996, p.13-52.

Between geography and philosophy: what does it mean to be in the placeworld? Annals of the Association of American Geographers, vol.91 (4), 2001, p.683-693.

DAMATTA, Roberto. A casa e a rua. São Paulo: Brasiliense, 1985.

\footnotetext{
${ }^{5}$ Lei No 10.098, de dezembro de 2000, regulamentada pelo Decreto-lei 5296 de dezembro de 2004.

${ }^{6}$ O Centro Cultural Banco do Brasil (CCBB) do Rio de Janeiro manteve programação com exibição de filmes com audiodescrição mensalmente, um final de semana por mês, em um horário na parte da tarde. O projeto "Acessibilidade no Teatro" levou audiodescrição e libras para os primeiros e terceiros domingos de cada mês no teatro Carlos Gomes.

${ }^{7}$ A iniciativa do Jardim sensorial, do Jardim Botânico, é um exemplo nesse sentido. Apesar da importância histórica, cultural, científica e paisagística do parque, que é tombado pelo Instituto do Patrimônio Histórico e Artístico Nacional, a área de acessibilidade se restringe ao local separado do jardim sensorial. As placas em Braille, por exemplo, se limitam ao circuito do jardim sensorial, não existem ao redor do parque, assim como não há caminhos com indicações táteis ou guia para deficientes visuais no circuito mais amplo ou ainda uma maquete do parque inteiro, por exemplo.
} 
DELEUZE, Gilles \& GUATTARI, Félix. Mil platôs: capitalismo c esquizofrenia, vol. 4. São Paulo: editora 34, 1997.

$\&$ . Mil Platôs: capitalismo e esquizofrenia, vol. 1. São

Paulo: editora 34, 1995.

GOFFMAN, Erving. Behaviour in Public Places. New York: The Free Press, 1966. . The Arrangement between the sexes. Theory and Society, Autumn, 1977, p.301-331.

GUATTARI, Félix \& ROLNIK, Suely. Micropolítica: cartografias do desejo. Petrópolis: Vozes, 1996.

HALBWACHS, Maurice. A memória coletiva. São Paulo: Vértice, 1990.

INGOLD, Tim. Lines: a brief history. New York: Routledge, 2007.

KOSEL, Salate. Comunicando e representando: mapas como construções socioculturais. Geograficidade, primavera, 2013, p.58-70.

LATOUR, Bruno; NOVEMBER, Valérie \& CAMACHO-HÜBNER, Eduardo. Entrando em território arriscado: o espaço na era da navegação digital. Terra Brasilis (Nova Série) [online], vol. 2, 2013. Disponível em: http://terrabrasilis.revues.org/903. Acesso em: 12 set.2014.

LEFÉBVRE, Henri. O Direito à Cidade. São Paulo: Documentos, 1969.

MAGNANI, José Guilherme C. Quando o campo é a cidade. In: MAGNANI, J. G C. \& TORRES, L. de L. (Orgs.) Na Metrópole: textos de Antropologia Urbana. São Paulo: EDUSP, 1996.

De perto e de dentro: notas para uma etnografia urbana. Revista brasileira de ciências sociais, vol.17 (49), 2002. p. 11-29.

NOGUEIRA, Amélia Regina Batista. Mapa mental: recurso didático para estudo do lugar. In: PONTUSCHKA, N. \& OLIVEIRA, A. Geografia em perspectiva: ensino e pesquisa. São Paulo: Contexto, 2002, p.125-130.

PARK, Robert E. The City: Suggestions for Investigation of Human Behavior in the Urban Environment. In: BURGESS, E. W. \& PARK, R. E. (orgs.). The City. Chicago: The University of Chicago Press, 1984.

PERLONGHER, Nestor. O negócio do Michê. São Paulo: Fundação Perseu Abramo, 2008.

POLLACK, Michael. Memória e identidade social. Estudos Históricos. Rio de Janeiro, vol. 5 (10), 1992. p. 200-212.

TUAN, Yi-Fu. Space and Place: the perspective of experience. London: University of Minnesota Press, 2001.

URRY, John \& BÜSCHER, Monika. Mobile Methods and the Empirical. European Journal of Social Theory, vol 12(1), 2009, p. 99-116. 
VYGOTSKY, Lev. S. Fundamentos de defectologia. In: VYGOTSKY, L. S. Obras escogidas. Madrid: Visor, 1997.

Recebido em: 29/09/2014

Aprovado em: 15/11/2014 